\title{
Refleksi Peran Mahkamah Konstitusi Dalam Penyelesaian Sengketa Pemilihan Umum 2004
}

\author{
Sri Hastuti Puspitasari \\ Fakultas Hukum Universitas Islam Indonesia \\ Jl. Taman Siswa No 158 Yogyakarta \\ e-mail : hastuti@fh.uii.ac.id
}

\begin{abstract}
The changes of UUD 1945 has an implication on the establishment of Constitution Justice. One of the authorities of the institution whose authority is in the same line with Supreme Court is the dispute settlement of General Election results. The role played by Constitution Justice, once it solved the dispute of the result of general election in 2004, proved that the principals of court justice have been implemented in order to keep the democracy and to establish the constitution.
\end{abstract}

Key words: : the Role of Constitutional Court, Election Dispute Settlement

\section{Pendahuluan}

Reformasi politik pada tahun 1998 telah membawa pengaruh sangat besar pada tatanan politik di Indonesia. Rezim pasca Orde Baru mempunyai agenda untuk melahirkan sistem politik demokratis, termasuk menjalankan Pemilihan Umum yang demokratis. Konseptualisasi tentang Pemilu yang demokratis dalam sistem politik yang demokratis pada dasarnya harus didukung oleh lembaga peradilan yang independen. Keberadaan dan peran lembaga peradilan sebagai pilar demokrasi akan ikut memberikan arah bagi terwujudnya pemilihan umum yang demokratis melalui kewenangannya yang bersifat represif yaitu menegakkan hukum atas pelanggaran-pelanggaran electoral law. Dengan demikian, pemilihan umum yang demokratis tidak hanya dilihat sebagai tata cara yang telah memenuhi kaidah normatif dan berhenti ketika etape pemilihan umum telah selesai, tetapi demokratisasi pemilihan umum itu akan dilihat pula dari aspek enforcement atas pelanggaran Pemilu maupun perselisihan hasil pemilihan umum. 
Enforcement atas perselisihan hasil pemilihan umum di Indonesia sejak Pemilihan Umum kedua dari rezim reformasi pada tahun 2004 telah dimulai oleh Mahkamah Konstitusi. Mahkamah Konstitusi (MK) merupakan lembaga yang terbentuk sebagai konsekuensi dari adanya reformasi ketatanegaraan melalui perubahan terhadap UUD 1945.

Mahkamah Konstitusi merupakan fenomena baru, terutama di negaranegara yang baru mengalami pergantian rezim dari otoritarian ke rezim demokratis, seperti Afrika Selatan, Korea Selatan, Lithuania, dan Ceko. ${ }^{1}$ Gagasan kelahiran Mahkamah Konstitusi di Indonesia juga tidak terlepas dari pergantian rezim dari Otoritarian Orde Baru ke rezim transisi menuju demokrasi dan sistem politik yang dibangun Indonesia pasca Orde Baru mengarah pada sistem politik demokratis. Secara normatif, sistem politik demokrasi terikat dengan indikator sistem politik demokratis yang oleh Robert Dahl meliputi hal-hal sebagai berikut: ${ }^{2}$. Control over governmental decision about policy is constitutionally vested in elected officials; 2 . Elected official are chosen and peacefully removed in relatively frequent, fair. Free election in which coercion is quite limited; 3. Practically all adults have the rights to vote in these elections; 4 . Most adults have the rights to run for public offices for which candidate run in these election; 5. Citizen have an effectively enforced rights to freedom of expression, particularly political expression, including criticism of the officials, the conduct of the government, the prevailing political, economic, and social system, and dominant ideology; 6 . They also have aces to alternative sources of information that are note monopolized by government or any other single group; 7. Finally they have and effectively enforced right to form and join autonomous associations, including political parties and interest group that attempt to influence the government by competing in elections and by other peaceful means.

Dalam konteks sistem politik demokratis, lembaga peradilan dapat memainkan peran yang sangat vital. Lembaga itu tidak hanya akan menjadi lembaga penegakan keadilan prosedural tetapi juga akan menegakkan keadilan secara substansial dengan menunjukkan perannya yang tidak sekedar menjadi corong undang-undang. Gagasan mendirikan Mahkamah Konstitusi menjadi oase bagi krisis nilai keadilan substansil,

${ }^{1}$ Lihat dalam Jimly Asshiddiqie, Format Kelembagaan Negara dan Pergeseran Kekuasaan Dalam UUD 1945, Cet. I, 2004, FH UII Press, Yogyakarta, hlm. 89

${ }^{2}$ Indikator-indikator tersebut dikemukakan oleh Robert A Dahl, sebagaimana dikutip oleh Affan Gafar, Politik Indonesia; Transisi Menuju Demokrasi, cet. ke II, Pustaka Pelajar, Jogjakarta, 2000, hlm. 7. 
terutama terkait dengan perlindungan hak-hak konstitusional warga negara yang selama rezim Orde Baru tidak mendapat perhatian optimal, bahkan oleh lembaga peradilan sekalipun.

Realisasi pembentukan Mahkamah Konstitusi baru terjadi ketika Indonesia melakukan perubahan terhadap konstitusinya. Perubahan konstitusi merupakan salah satu cara untuk melakukan restrukturisasi kelembagaan negara dengan cara konstruktif dan legal. Munculnya Mahkamah Konstitusi melalui amandemen UUD 1956 merupakan langkah yang sangat positif, konstruktif dan strategis bagi kehidupan ketatanegaraan Indonesia.

Pengaturan Mahkamah Konstitusi dalam UUD 1945 meliputi aspek kedudukan, tugas dan kewenangan, keanggotaan hakim dan prasyaratnya. Mahkamah Konstitusi sebagai bagian kekuasaan kehakiman mempunyai tugas untuk menyelenggarakan peradilan guna menegakkan hukum dan keadilan secara merdeka (Pasal 24 ayat (1)).

Kewenangan Mahkamah Konstitusi yang diberikan melalui Pasal 24C ayat (1) dan ayat (2) UUD 1945 meliputi: 1. Menguji undang-undang terhadap UUD; 2. Memutus sengketa kewenangan lembaga negara yang kewenangannya diberikan oleh UUD; 3 . Memutus pembubaran partai politik; 4 . Memutuskan perselisihan tentang hasil pemilihan umum; 5. Memutuskan pendapat DPR tentang dugaan pelanggaran yang telah dilakukan oleh Presiden dan/atau Wakil Presiden; ${ }^{3}$

Selain itu, dalam Pasal 7B UUD 1945, Mahkamah Konstitusi juga berwenang memutuskan pendapat DPR bahwa Presiden dan/atau Wakil Presiden tidak lagi memenuhi persyaratan.

\section{Mahkamah Konstitusi dan Penyelesaian Sengketa Hasil Pemilihan Umum}

Khusus kewenangan Mahkamah Konstitusi dalam menyelesaikan perselisihan hasil pemilihan umum, hal itu merupakan kewenangan yang sejalan dengan iklim demokratisasi yang kini tengah dibangun oleh Indonesia. Kewenangan ini selain menciptakan balancing power antar organ negara, juga memberi peluang bagi masyarakat yang dirugikan hak-haknya dalam pemilu untuk mencari keadilan melalui Mahkamah Konstitusi dalam iklim politik demokratis. Henry W Ehrmann, merujuk

${ }^{3}$ Dugaan pelanggaran ini meliputi pengkhianatan terhadap negara, korupsi, penyuapan, tindak pidana berat lainnya dan perbuatan tercela. 
praktek demokrasi di beberapa negara, menambahkan dua prinsip dalam sistem politik demokratis. Pertama, the balancing function of the separation power between government, parliament, and judiciary. Kedua, free choice of alternative is much important for a substantial participation of the people. ${ }^{4}$ Atas dasar prinsip tersebut, keberadaan Mahkamah Konstitusi dengan kewenangannya dalam menyelesaikan sengketa hasil pemilihan umum akan memberi kontribusi positif bagi sistem politik demokrasi. Sistem politik demokrasi di negara manapun tidak bisa mengabaikan dua prinsip mendasar tersebut.

Selanjutnya, Michael Saward mengemukakan bahwa demokratisasi sebuah sistem memerlukan beberapa kondisi minimal seperti jaminan basic freedom (freedom of speech an d expression, freedom of movement, freedom of association, rights to equal treatment under the law); citizenship and participation; administrative code; publicity and social rights. ${ }^{5}$ Selain itu, ada sejumlah nilai atau prinsip-prinsip politik untuk menjalankan bersama-sama prinsip demokrasi yakni political stability; justice; nationalism; the environtmental imperative; and efficiency. ${ }^{6}$ Berdasarkan sejumlah prinsip tersebut, Pemilu dalam sistem politik apapun akan mengundang terjadinya instabilitas. Upaya menciptakan kondisi yang stabil, tidak semata-mata didasarkan pada faktor pertahanan-kemanan saja, tetapi stabilitas akan terjaga jika ada prinsip keadilan. Nilai keadilan akan sangat sulit dicapai jika tidak ada lembaga yang mempunyai kewenangan menegakkan hukum dan keadilan secara independen. Disinilah letak urgennya lembaga peradilan seperti Mahkamah Konstitusi dalam proses demokrasi karena proses demokrasi itu sendiri sering menjadikan pelanggaran sebagai suatu hal wajar, padahal hal itu berpotensi menimbulkan konflik dan ketidakadilan.

Peran Mahkamah Konstitusi dalam penyelesaian sengketa hasil Pemilu juga dapat dimaknai sebagai bagian dari tanggungjawab negara dalam mewujudkan Pemilu demokratis yang kaidahnya secara internasional dirumuskan oleh Dewan Antar Parlemen sedunia dalam sidangnya yang ke-154 di Paris tahun 1994. Terdapat beberapa persyaratan yang menjadi

\footnotetext{
${ }^{4}$ Henry W Ehrimann (edt), Democracy in Changing Society,Frederick A Preager Publishers, USA, 1964, hlm. 10-11

${ }^{5}$ Michael Saward, Democratic Theory and Indices Of Democratization dalam David Beetham (edt) Defining and Measuring Democrcy, Sage Publication,Ltd London, 1994, hlm. 16-17

${ }^{6} \mathrm{Ibid}, \mathrm{hlm} .20$
} 
hak dan tanggungjawab Negara, yang meliputi: ${ }^{7}$ 1) negara harus mengambil langkah-langkah legislatif dan tindakan lain yang diperlukan sesuai dengan proses konstitusionalnya untuk menjamin hak-hak dan kerangka institusional untuk Pemilu yang periodik, murni, bebas dan adil, sesuai dengan kewajibannya menurut UU Internasional, yang meliputi: menyusun sebauh prosedur yang efektif, tidak memihak dan tidak diskriminatif untuk pendaftaran pemilih; menyusun kriteria yang jelas untuk pendaftaran pemilih menurut usia, kewarganegaraan dan tempat tinggal, serta menjamin bahwa ketentuan itu dilaksanakan tanpa perbedaan apapun; menunjang terbentuknya dan berfungsinya secara bebas partai-partai politik, sedapat mungkin mengatur pembiayaan partaipartai politik dan kampanye Pemilu, menjamin pemisahan antara partai dengan Negara, dan menciptakan kondisi untuk persaingan dalam pemilihan legislatif atas dasar persamaan derajat; 2) mengambil kebijakan dan langkah-langkah institusional guna kemajuan pencapaian dan konsolidasi cita-cita demokratis, termasuk pembentukan mekanisme yang netral dalam penyelenggaraan Pemilu, yang mencakup: tanggungjawab menyediakan tenaga terlatih dan tidak memihak, serta prosedur Pemilu yang diberitahukan kepada masyarakat; menjamin pendaftaran pemilih, memperbaharui daftar pemilih dan prosedur pemungutan suara; mendorong partai-partai, para calon dan media untuk menjalankan code of conduct (kode etik) untuk mengatur kampanye Pemilu dan pemungutan suara; menjamin integritas kotak suara melalui langkah-langkah tepat untuk mencegah pemberian suara ganda, atau pemberian suara oleh mereka yang tidak berhak; menjamin integritas proses penghitungan suara; 3) negara harus menghormati dan menjamin hak asasi setiap orang dan harus tunduk pada perundang-undangannya; 4) negara harus mengambil langkah-langkah yang perlu agar partai dan para calonnya memperoleh kesempatan yang cukup untuk membeberkan platform pemilunya; 5) negara harus menjamin prinsip pencoblosan secara rahasia, pemilih dapat memberikan suaranya dengan bebas, tanpa rasa takut atas intimidasi; 6) negara harus menjamin pencoblosan terhindar dari pemalsuan dan hal-hal yang tidak sah, penghitungan suara dilakukan

${ }^{7}$ Prasyarat-prasyarat tersebut dikutip dari buku Free and Fair Election:International law and Practices, yang ditulis oleh Guy S. Goodwin-Gill, Inter Parliamentary Union, Geneva, 1994, sebagaimana telah diterjemahkan oleh Nurhasan: Pemilu Jurdil: Pengalaman dan Standart Internasional, diterbitkan oleh PIRAC dan The asia Foundation, Jakarta, 1999, hlm. xxii-xxvii 
oleh tenaga terlatih, boleh dipantau dan/atau diverifikasi secara adil; 7) negara menjamin transparansi dari seluruh proses Pemilu; 8) negara menjamin bahwa partai-partai dan para calon serta para pendukung memperoleh pengamanan bersama, negara harus mencegah terjadinya kekerasan dalam pemilu; 9) negara menjamin bahwa pelanggaran hak asasi dan segala pengaduan berkaitan dengan proses Pemilu ditangani segera dalam periode proses pemilu dan secara efektif oleh lembaga independen yang tidak memihak, seperti komisi pemilu atau pengadilan.

Setelah Pemilu dan Pemilihan Presiden 2004, Mahkamah Konstitusi menerima perkara yang berkaitan dengan sengketa hasil Pemilihan Umum. Legalitas Mahkamah Konstitusi menangani perkara sengketa hasil Pemilihan Umum adalah Pasal 24C ayat (1), Pasal 74 dan 75 UU No 24 Tahun 2003 tentang Mahkamah Konstitusi, dan Pasal 134 UU No 12 tahun 2003 tentang Pemilihan anggota DPR, DPD, DPRD. Pemohon dalam sengketa hasil Pemilu adalah warga negara Indonesia perseorangan calon anggota DPD peserta Pemilu, Partai politik, dan pasangan calon Presiden dan calon Wakil Presiden. Berkait dengan sengketa Pemilu, Mahmakah Konstitusi telah mengeluarkan 2 (dua) Peraturan, yaitu Peraturan Mahkamah Konstitusi No. 04/PMK/2004 tentang Pedoman Beracara dalam Perselisihan Hasil Pemilu, dan Peraturan Mahkamah Konstitusi No 05/PMK/2004 tentang Prosedur Pengajuan Keberatan atas Penetapan Hasil Pemilu Presiden dan Wakil Presiden. Sesuai dengan ketentuan Pasal 24C ayat (1) Undang-Undang Dasar Negara Republik Indonesia Tahun 1945 (selanjutnya disebut UUD 1945) dan Pasal 10 ayat (1) UndangUndang Nomor 24 Tahun 2003 Tentang Mahkamah Konstitusi, salah satu kewenangannya ialah memutus perselisihan hasil pemilihan umum (selanjutnya disingkat Pemilu). Pemilu yang dimaksud adalah Pemilu Anggota DPR, DPD, dan DPRD, serta Pemilu Presiden dan Wakil Presiden (vide Pasal 22E ayat (2) UUD 1945). Kemudian Pasal 85 UndangUndang Nomor 23 Tahun 2003 Tentang Pemilihan Umum Presiden dan Wakil Presiden (selanjutnya disingkat UU Pilpres) menentukan "Dalam hal terjadi perselisihan tentang hasil Pemilu Presiden dan Wakil Presiden sebagaimana dimaksud dalam Pasal 68, diperiksa dan diputuskan untuk tingkat pertama dan terakhir oleh Mahkamah Konstitusi". Berdasarkan hal-hal tersebut di atas, Mahkamah berwenang untuk memeriksa, mengadili, dan memutus permohonan a quo.

Kedudukan hukum (legal standing) Pemohon pada Pasal 74 ayat (1), (2), dan (3) UUMK juncto Pasal 68 ayat (1) dan (2) UU Pilpres menentukan 
hal-hal antara lain sebagai berikut: a. Pemohon adalah pasangan calon Presiden dan Wakil Presiden peserta Pemilu Presiden dan Wakil Presiden; b. Permohonan hanya dapat diajukan terhadap penetapan hasil Pemilu yang dilakukan secara nasional oleh KPU yang mempengaruhi penentuan pasangan ; c. calon yang masuk pada putaran kedua pemilihan Presiden dan Wakil Presiden serta terpilihnya pasangan calon Presiden dan Wakil Presiden; d. Permohonan hanya dapat diajukan dalam jangka waktu paling lambat $3 \times 24$ (tiga kali dua puluh empat) jam sejak KPU mengumumkan penetapan hasil Pemilu secara nasional.

Pada Pemilu 2004, permohonan keberatan atas penetapan hasil Pemilu oleh KPU yang diajukan ke Mahkamah Konstitusi berjumlah 448 (empat ratus empat puluh delapan). Jumlah tersebut terdiri dari 23 (dua puluh tiga) permohonan tidak diregistrasi karena tidak memenuhi persyaratan, 152 (seratus lima puluh dua) tidak diregistrasi karena bukan merupakan perkara sengketa Pemilu, dan sisanya sebanyak 273 (dua ratus tujuh puluh tiga) diregistrasi karena memenuhi persyaratan dan merupakan perkara sengketa Pemilu. Permohonan yang diregistrasi meliputi 252 (dua ratus lima puluh dua) diajukan oleh Partai Politik, dan 21 (dua puluh satu) diajukan oleh calon anggota DPD. Dari jumlah yang diajukan oleh Partai Politik, sejumlah 131 (seratus tiga puluh satu) perkara ditolak, tidak diterima 74 (tujuh puluh empat) perkara tidak diterima, dan 9 (sembilan) perkara ditarik kembali, sehingga total yang diterima adalah 38 (tiga puluh delapan) Perkara. Kemudian, untuk perkara yang diajukan oleh calon anggota DPD, 3 (tiga) perkara dikabulkan, 3 (tiga) perkara ditolak, dan 15 (lima belas) permohonan tidak diterima. ${ }^{8}$ Sedangkan untuk perselisihan hasil Pemilihan Presiden dan Wakil Presiden, ada 1 (satu) permohonan yang diajukan oleh Calon Presiden Wiranto, dan ditolak oleh Mahkamah Konstitusi.

Beberapa contoh kasus sengketa hasil Pemilu yang diajukan kepada Mahkamah Konstitusi adalah: 1. Sengketa Hasil Pemilihan Anggota DPD. Putusan Perkara Nomor 025/PHPU.A-II/2004. Pemohon dalam perkara ini adalah H. Ace Suhaedi Madsupi, calon anggota DPD Provinsi Banten yang keberatan terhadap Penetapan Hasil Pemilihan Umum dari Komisi Pemilihan Umum tanggal 5 Mei 2004 untuk daerah pemilihan Provinsi Banten. Menurut Pemohon, terdapat kesalahan penghitungan suara sehingga pemohon dirugikan. Penetapan hasil Pemilu dari KPU menetapkan suara yang diperoleh pemohon adalah 73.077 dan untuk

\footnotetext{
${ }^{8}$ Soedarsono, Op.Cit, hlm. 208
} 
Kecamatan Jawilan sebanyak 1437. Pemohon mengklaim bahwa suara yang benar adalah 159.264, dan untuk Kecamatan Jawilan sebanyak 2817. Dengan demikian, pemohon mengklaim telah kehilangan suara sebanyak 69.567 suara. Maka dari itu, Pemohon memohon kepada Mahkamah Konstitusi untuk mengabulkan permohonan pemohon dan membatalkan Penetapan Hasil Pemilihan Umum dari KPU. Mahkamah Konstitusi membandingkan bukti-bukti Pemohon dengan dokumen-dokumen yang ada dan dokumen yang digunakan oleh Panitia Pengawas Pemilu Provinsi Banten. Ternyata tidak ada bukti kesalahan penghitungan oleh KPU. Di samping itu, dalam persidangan juga terdapat fakta bahwa Pemohon tidak melakukan keberatan terhadap jalannya penghitungan suara di TPS, PPS, PPK,dan KPU Kota. Maka dari itu Mahkamah Konstitusi memberi keputusan bahwa permohonan pemohon tidak dapat diterima (niet onvantkelijk verklaard); ${ }^{9}$ 2. Sengketa Hasil Pemilihan Anggota DPD. Putusan Perkara No.14/PHPU.A-II/2004 yang dilakukan oleh Pemohon KH. Ahmad Chalwani sebagai Pemohon I, dan Drs. Dahlan Rais M.Mhum, sebagai Pemohon II. Keduanya adalah calon anggota DPD Provinsi Jawa Tengah. Menurut Penetapan Hasil Pemilihan Umum dari KPU, KH. Ahmad Chalwani memperoleh suara sejumlah 875.710 dan berada di urutan ke 5 (lima), sedangkan Drs, Dahlan Rais M.Hum, memperoleh sejumlah 894.271 suara. Pemohon I mengajukan keberatan atas Penetapan Hasil Pemilihan Umum dari KPU, terutama perhitungan suara di Kabupaten Purbalingga, Purworejo, Semarang, Grobogan dan Wonosobo. Sedangkan Pemohon II mengajukan keberatan atas perhitungan suara di Kabupaten Purbalingga, Purworejo, Wonosobo, Pemalang, Semarang, Klaten, Blora, Batang, dan Banyumas. Baik pemohon I maupun Pemohon II berpendapat telah terjadi kesalahan penghitungan hasil Pemilu sehingga merugikan Pemohon. Sesuai dengan Pasal-pasal Undang-Undang Dasar Negara Republik Indonesia Tahun 1945, Undang-undang Nomor 12 Tahun 2003, dan Undang-undang Nomor 24 Tahun 2003 tersebut di atas serta peraturan perundang-undangan lain yang berlaku dalam permohonan ini. Berdasarkan perkara No 14-027/PHPU.A-II/ 2004 tersebut setidaknya terdapat 4 (empat) substansi yang diputuskan oleh mahkamah Konstitusi, yaitu: a. Mahkamah Konstitusi mengabulkan permohonan Pemohon I dan Pemohon II; b. Menyatakan batal Keputusan Komisi Pemilihan Umum (KPU) Nomor 44/SK/KPU/2004 tentang

\footnotetext{
${ }^{9}$ Lihat Putusan Perkara Nomor 025/PHPU.A-II/ 2004.
} 
Penetapan Hasil Pemilu Anggota DPR, DPD, DPRD Provinsi dan DPRD Kabupaten/Kota dalam Pemilu tahun 2004, lampiran II/13 Hasil penghitungan suara anggota DPD dalam Pemilu tahun 2004 Provinsi Jawa Tengah sepanjang menyangkut hasil penghitungan suara bagi Para Pemohon; c. Menetapkan hasil penghitungan suara yang benar sebagai berikut: Pemohon I .H. Achmad Chalwani : 881.050 suara, Pemohon II Drs. Dahlan Rais, M.Hum. : 880.774 suara.; d. Memerintahkan kepada KPU untuk melaksanakan putusan ini.; 3. Sengketa Hasil Pemilihan Umum yang diajukan oleh Partai Politik. Putusan Perkara No 015/PHPU-C I-II/2004, dengan Pemohon Erros Djarot dan Suhardi Sudiri, Ir., MSc, keduanya bertindak untuk dan atas nama Partai Nasional Banteng Kemerdekaan (PNBK). Pemohon keberatan terhadap Penetapan Hasil Pemilihan Umum dari KPU yang merugikan PNBK. Menurut pemohon, ada kesalahan penghitungan di daerah Bali yaitu daerah pemilihan 3 Gianyar, dan Jembrana; di Sumatra Utara yang meliputi Kota Binjai, Deli Serdang, daerah pemilihan 1 Tapanuli, daerah pemilihan I Toba Samosir, Sibolga; di Papua; Kalimantan Barat; dan Sulawesi Tenggara. Dalam putusannya, Mahkamah Konstitusi mengabulkan sebagian permohonan pemohon dan menolak sebagian permohonan pemohon. Kutipan putusan Mahkamah Konstitusi sebagai berikut: a. Mengabulkan permohonan Pemohon untuk sebagian; $b$. Membatalkan Keputusan Komisi Pemilihan Umum Nomor 44/SK/KPU/ Tahun 2004 tanggal 5 Mei 2004 sepanjang menyangkut perolehan suara Partai Nasional Banteng Kemerdekaan untuk: (1) Calon Anggota Dewan Perkawilan Rakyat Daerah Kabupaten Gianyar dari Daerah Pemilihan 3 Gianyar, (2) Calon Anggota Dewan Perwakilan Rakyat Daerah Kota Binjai dari Daerah Pemilihan 2 Binjai dan perolehan suara Partai Golongan Karya untuk Calon Anggota Dewan Perwakilan Rakyat Daerah Kota Binjai dari Daerah Pemilihan 2 Binjai. c. Menetapkan perolehan suara yang benar bagi Partai Nasional Banteng Kemerdekaan untuk : (1) Calon Anggota Dewan Perwakilan Rakyat Daerah Kabupaten Gianyar di Daerah Pemilihan 3 Gianyar adalah 2.166 suara, (2) Calon Anggota Dewan Perwakilan Rakyat Daerah Kota Binjai di Daerah Pemilihan 2 Binjai adalah 1.565 suara, dan perolehan suara untuk Partai Golkar di Daerah Pemilihan 2 Binjai adalah 8.206 suara; d. Menyatakan permohonan Pemohon untuk : (1) Calon Anggota Dewan Perwakilan Rakyat Daerah dari Daerah Pemilihan 2 dan 3 Kabupaten Deli Serdang, (2) Calon Anggota Dewan Perwakilan Rakyat dari Daerah Pemilihan Kalimantan Barat, (3) Calon Anggota Dewan Perwakilan Rakyat Daerah dari Daerah Pemilihan 2 Kota Sibolga, tidak 
dapat di terima (niet ontvankelijk verklaard); e. Menolak permohonan Pemohon untuk selebihnya; f. Memerintahkan Komisi Pemilihan Umum untuk melaksanakan putusan ini.; 4. Sengketa Pemilihan Presiden dan Wakil Presiden. Dalam Putusan Perkara Nomor 062/PHPU-B-II/2004, Pemohon pasangan calon Presiden dan calon Wakil Presiden dari Partai Golkar yaitu H Wiranto S.H., dan Ir. H Salahudin Wahid mengajukan keberatan dan tidak dapat menerima Keputusan KPU Nomor 79/SK/KPU/Tahun 2004 tanggal 26 Juli 2004 tentang Penetapan dan Pengumuman Hasil Penghitungan Suara Hasil Pemilihan Umum Presiden dan Wakil Presiden dan Berita Acara Rekapitulasi Hasil Penghitungan Suara Pemilihan Umum Presiden dan wakil Presiden oleh KPU Nomor 125/15-BA/VII/2004, dengan alasan telah terjadi kesalahan dan kekeliruan penghitungan suara baik disengaja maupun tidak disengaja oleh KPU yang mengakibatkan Pemohon kehilangan suara yang sugnifikan sehingga posisi Pemohon berada di urutan Nomor 3 (tiga) sehinga tidak masuk pada putaran kedua Pemilihan Umum Presiden. Dalam persidangan tersebut, KPU sebagai Termohon memberikan keterangan yang intinya menyatakan bahwa permohonan Pemohon harus dinyatakan tidak dapat diterima atau setidaktidaknya ditolak dengan alasan: a. Permohonan Pemohon tidak memenuhi persyaratan formal sebuah permohonan sengketa Pemilihan Umum sebagaimana dinyatakan oleh peraturan perundang-undangan. $b$. Permohonan kabur atau tidak jelas (obscuur libel). Persidangan juga dihadiri sejumlah saksi, termasuk saksi ahli Roy Suryo ( pakar telematika) dan Prof. Dr. Harun Al-Rasyid (pakar Hukum Tata Negara). Dalam Putusannya, Mahkamah Konstitusi menyatakan bahwa dalil Pemohon bahwa telah kehilangan suara di sejumlah Provinsi ternyata tidak terbukti setelah meneliti satu demi satu secara cermat perolehan suara di 26 Provinsi yang dipermasalahkan oleh Pemohon sebagaimana telah diuraikan di atas, Mahkamah berpendapat bahwa Pemohon telah ternyata tidak berhasil membuktikan dalil tentang kesalahan hasil penghitungan suara yang mengakibatkan Pemohon kehilangan sebesar 5.434.660 suara. Oleh karena permohonan Pemohon tidak beralasan, sehingga harus

${ }^{10}$ Provinsi yang dimaksud adalah Nangroe Aceh, Kepulauan Riau, Riau, Jambi, Sumatra Selatan, Bangka Belitung, Banten, DKI, Jawa Barat, DIY, Jawa Tengah, Jawa Timur, Bali, NTB, NTT, Kalimantan Barat, Kalimantan Tengah, Kalimantan Selatan, Kalimantan Timur, Sulawesi Utara, Sulawesi Tengah,Sulawesi Tenggara, Sulawesi Selatan, Gorontalo, Maluku Utara, dan Irian Jaya Barat. Lihat Putusan Mahkamah Konstitusi Nomor 062/PHPU-B-II/2004. 
ditolak. ${ }^{10}$ Maka dari itu, Mahkamah Konstitusi dalam putusannya menyatakan menolak permohonan Pemohon untuk seluruhnya.

Beberapa putusan sebagaimana diuraikan secara singkat di atas, membuktikan bahwa peran Mahkamah Konstitusi dalam menyelesaikan sengketa hasil Pemilihan Umum sangat urgen. Selain itu, persidangan yang digelar oleh Mahkamah Konstitusi dalam perkara sengketa hasil Pemilu, telah menunjukkan beberapa komitmen dan konsistensi sebagai lembaga penegak hukum dan keadilan dan merepresentasikan tanggungkjawab negara dalam mewujudkan Pemilu yang demokratis.

Putusan Mahkamah Konstitusi dalam perkara penyelesaian sengketa hasil Pemilu juga mencerminkan beberapa prinsip yaitu: 1. Prinsip Legalitas. Legalitas ini menyangkut legalitas permohonan, legalitas pemohon sebagai legal standing, dan legalitas kewenangan Mahkamah Konstitusi dalam menangani sengketa perselisihan hasil Pemilu; 2. Prinsip Akurasi bukti kuantitatif. Sengketa Perselisihan Hasil Pemilu pada umumnya berkaitan dengan klaim-klaim kekeliruan penghitungan suara yang telah dilakukan oleh KPU. Para Pemohon umumnya merasa sangat dirugikan atas penetapan hasil pemungutan suara sehingga menyebabkan suara bagi Pemohon atau partainya menjadi berkurang atau hilang. Maka dari itu, Mahkamah Konstitusi dituntut untuk melakukan cross check bukti kuantitatif yang akurat pula sehingga keputusannya benar-benar memberi keadilan, baik bagi Pemohon maupun bagi Termohon. Hal itu dapat dilihat pada contoh ke 2 (dua) di atas, dalam Putusan Perkara No.14/PHPU.AII/2004 yang dilakukan oleh Pemohon KH. Ahmad Chalwani sebagai Pemohon I, dan Drs. Dahlan Rais M.Mhum sebagai Pemohon II, keduanya calon anggota DPD Provinsi Jawa Tengah. Bukti yang diajukan para Pemohon benar-benar harus diuji secara faktual, dengan bukti yang akurat pula; 3. Prinsip Transparansi. Mahkamah Konstitusi melakukan persidangan dalam perkara perselisihan hasil Pemilu secara terbuka, sehingga memungkinkan pihak-pihak yang terkait dengan sengketa maupun masyarakat mengikuti dan memantau jalannya persidangan; 4 . Prinsip Imparsialitas. Pemilu merupakan peristiwa yang rentan dengan kepentingan politik. Maka dari itu peradilan yang digelar Mahkamah Konstitusi merupakan peradilan untuk menegakkan hukum dan keadilan, bukan peradilan untuk memenangkan kepentingan tertentu dari pihakpihak yang mengajukan perkara; 5. Prinsip Obyektifitas dan Profesionalitas Hakim. Meskipun diantara para hakim konstitusi ada yang dulunya merupakan anggota partai politik tertentu, tetapi dalam 
menangani perkara sengketa hasil Pemilu para hakim konstitusi dituntut obyektif, harus dapat melepaskan "baju" kepartaiannya dan bekerja secara profesional. Dengan begitu, martabat hakim konstitusi terjaga dari kepentingan politik praktis.

\section{Penutup}

Pemilu 2009 semakin dekat dan kemungkinan MK akan menerima lebih banyak perkara sengketa hasil Pemilu. Apa yang telah diperankan MK dalam menyelesaikan sengketa hasil Pemilu 2004 merupakan refleksi bagi MK untuk tetap mempertahankan prinsip-prinsip yang telah tercermin dalam putusan-putusannya.

Permohonan sengketa hasil Pemilu kepada MK dan proses hukum atas perkara tersebut yang telah berjalan akan memperkuat posisi MK dalam menegakkan pilar demokrasi. Selain itu, kewenangan tersebut merupakan wujud dari tanggungjawab negara dalam menegakkan prinsip Pemilu demokratis sesuai dengan prasyarat kesembilan dari hak dan tanggungjawab negara dalam mewujudkan Pemilu demokratis, yaitu negara menjamin bahwa pelanggaran hak asasi dan segala pengaduan berkaitan dengan proses Pemilu ditangani segera dalam periode proses pemilu dan secara efekfif oleh lembaga independen yang tidak memihak, seperti komisi pemilu atau pengadilan.

\section{Daftar Pustaka}

Jimly, Asshiddiqie, Format Kelembagaan Negara dan Pergeseran Kekuasaan Dalam UUD 1945, Cet. I, Yogyakarta: FH UII Press, 2004.

Henry W (edt),Ehrimann, Democracy in Changing Society,Frederick A Preager Publishers, USA, 1964.

Gill,Guy S. Goodwin, Free and Fair Election:International law and Practices, Inter Parliamentary Union, Geneva, 1994, diterjemahkan oleh Nurhasan (Pemilu Jurdil: Pengalaman dan Standart Internasional), diterbitkan oleh PIRAC dan The Asia Foundation, Jakarta, 1999

Affan Gafar, Politik Indonesia; Transisi Menuju Demokrasi, cet ke II, Jogjakarta : Pustaka Pelajar, 2000.

IDEA, Penilaian demoratisasi di Indonesia, Stocholm, Swedia : International IDEA, 2000.

Mahkamah Konstitusi RI, Putusan Perkara No.14/PHPU.A-II/2004 
Mahkamah Konstitusi RI, Putusan Perkara No 015/PHPU-C I-II/2004 Mahkamah Konstitusi RI, Putusan Perkara Nomor 025/PHPU.A-II/2004 Mahkamah Konstitusi RI, Putusan Perkara Nomor 062/PHPU-B-II/2004 Republik Indonesia, Undang-Undang Dasar 1945 Setelah Perubahan ,Undang-Undang No 12 Tahun 2003 tentang Pemilu ,Undang-Undang No 23 Tahun 2003 tentang Pemilihan Presoden dan wakil Presiden ,Undang-Undang No 24 Tahun 2003 tentang Mahkamah Konstitusi.

Michael, Saward, 1994. Democratic Theory and Indices Of Democratization dalam David Beetham (edt) Defining and Measuring Democrcy, Ltd London : Sage Publication

Sri Hastuti Puspitasari, " Pemilu dan Demokrasi: Telaah terhadap Prasyarat Normatif Pemilu", Jurnal Hukum, No 25 Vol 11-2004

Soedarsono, Mahkamah Konstitusi Sebagai Pengawal Demokrasi, Penyelesaian Sengketa Hasil Pemilu 2004 Oleh Mahkamah Konstitusi, Sekretariat Jenderal dan Kepaniteraan MKRI, Jakarta, 2005. 